\title{
Cement Mixtures Containing Copper Tailings as an Additive: Durability Properties
}

\author{
Obinna Onuaguluchi*, Özgur Eren \\ Department of Civil Engineering, Eastern Mediterranean University, \\ Famagusta, North Cyprus, via Mersin 10, Turkey
}

Received: October 16, 2011; Revised: July 21, 2012

\begin{abstract}
The effects of copper tailings as an additive, on some durability properties of cement mixtures were investigated. In each mixture, copper tailings addition levels by mass were $0 \%, 5 \%$ and $10 \%$. Compared to the control samples, copper tailings blended pastes showed superior performance against autoclave expansion while insignificant decreases in sulfate resistance of mortars were observed. Copper tailings increased the water absorption and total permeable voids of concretes slightly. However, the compressive and flexural strengths of blended concretes were higher than those of the control samples. Similarly, improved resistance to acid attack and chloride penetration as the copper tailings content of concretes increased were also observed. Results further showed that the ASTM C 1202 rapid chloride permeability test may not be a valid indicator of chloride migration in mixtures containing conductive copper tailings. These results suggest that copper tailings can potentially enhance the durability properties of cement based materials.
\end{abstract}

Keywords: copper tailings, concrete, water absorption, durability and chloride penetration

\section{Introduction}

The rising demand for a cleaner environment and sustainability in the use of construction materials have renewed the clamor in the construction industry for increased recycling of industrial wastes as concrete making materials. These calls have become more strident given that several researchers have shown that the utilization of industrial by-products such as coal fly ash and silica fume as supplementary cementitious materials improve concrete durability significantly. Studies by Langely et al. ${ }^{1}$ suggested that at 91 days, fly ash concrete developed more strength than concretes without supplementary materials. Polder and Peelen ${ }^{2}$ were of the opinion that concrete containing blast furnace slag, fly ash or both has a superior resistance to chloride penetration and corrosion activity. Hou and Chung ${ }^{3}$ studied the effect of supplementary materials such as silica fume and carbon fibers on corrosion resistance; they concluded that silica fume is most effective in improving corrosion resistance because it decreases water absorption while increasing concrete resistivity. Related studies by Ganesan et al. ${ }^{4}$ and Cordeiro et al. ${ }^{5}$ showed that sugarcane bagasse ash blended concretes recorded enhanced strength and durability properties. Similarly, Chusilp et al..$^{6}$ observed that concrete containing up to $30 \%$ ground bagasse ash as cement replacement material showed higher compressive strength, lower water permeability and heat evolution compared to the control concrete at 28 and 90 days. Given the various benefits accruable from the use of these aforementioned waste materials in concrete, it is imperative

*e-mail: luchiobinna@yahoo.com that the utilization of other categories of waste materials in cement based mixtures be investigated.

Today, copper and copper allied products have wide applications in various industries. Hence, with increasing world population, the demands for these aforementioned products will certainly increase. It was estimated that between 1900 and 2008, annual use of copper increased from less than 500 hundred thousand to 18 million metric tons $^{7}$. This invariably means that the waste generated at copper processing facilities across the world has increased significantly. The massive waste generation going on in the copper industry, was highlighted by Boger ${ }^{8}$ when he submitted that about 230,000 tons of dry copper tailings is produced daily at the Escondida copper mine in Chile. According to Yu et al. as cited in Huang et al., ${ }^{9}$ more than 2.4 billion tons of copper tailings can be presently found in China. Similar or higher volumes of copper tailings may also be in existence in major copper producing countries such as Chile, Peru and United States. It is expected that several billion tons of copper tailings will be produced in future.

Previous studies have shown that copper slag, which is less abundant in comparison to copper tailings, can enhance the mechanical and durability properties of mortar and concrete. Ayano and Sakata ${ }^{10}$ observed higher long-term compressive strength in concrete mixtures containing copper slag. They also noticed that these mixtures displayed no significant sulfate induced deterioration, and the rate of carbonation was minimal compared to those of the control samples. Moura et al. ${ }^{11}$ employed copper slag as an additive in concrete, and they observed increased mechanical strength, reduced porosity and carbonation 
for concrete samples. Al-Jabri et al. ${ }^{12}$ also submitted that the substitution of sand with copper slag improved the strength and durability properties of high strength concrete. Compared to the control mixture, Najimi et al. ${ }^{13}$ observed higher resistance to sulfate attack in concrete samples containing copper slag.

Till now, research studies on the durability properties of cement based mixtures containing copper tailings as an additive material are not available. Consequently, this paper investigated some durability properties of pastes, mortars and concretes incorporating copper tailings as an additive at $0 \%, 5 \%$ and $10 \%$ addition levels by mass.

\section{Experimental Works}

\subsection{Materials}

The binders used in preparing paste, mortar and concrete mixtures in this study were Portland slag cement CEM III/A (Class $32.5 \mathrm{~N}$ ) and copper tailings obtained at various depths from deposits at an abandoned processing facility at Lefke, Cyprus. The tailing samples were air dried and sieved with a $600 \mu \mathrm{m}$ sieve before usage. The fine and coarse aggregates were sourced from locally crushed rock while ASTM C $778^{14}$ standard sand and ASTM C $452^{15}$ specified high grade natural gypsum was used for the preparation of mortars. Similarly, a hydrochloric acid $(\mathrm{HCl})$ solution with a $\mathrm{pH}$ of 1.0 was used for the acid resistance tests.

\subsection{Physical and chemical properties of constituent materials}

Physical properties, such as the specific gravity of the cement and copper tailings, were determined according to the ASTM C $188^{16}$ specification. The specific surface areas were obtained using ASTM C $204{ }^{17}$ and Blaine's air permeability apparatus. The particle size distribution of the waste material was also determined using sieve analysis and a hydrometer method. Finally, an oxide analysis of the copper tailings was performed. The specific gravities of the fine aggregates, coarse aggregates and copper tailings were $2.77,2.54$ and 4.29 , respectively. The high specific gravity of the copper tailings was attributed to the high concentration of iron (III) oxide in it. Similarly, the water absorption property of the tailings (13.8\%) was much higher than the $0.13-0.55 \%$ recorded in literature for copper slag. It is suspected that prolonged exposure to weathering might have also contributed to the increased porosity of the tailings. The particle size distribution curve of the copper tailings is shown in Figure 1. The curve indicated that about $50 \%$ of the tailing particles were finer than $0.1 \mathrm{~mm}$. Some physical and chemical properties of cement and copper tailings are also shown in Table 1.

\subsection{Mixture proportions}

Pastes were prepared using $650 \mathrm{~g}$ of cement incorporating copper tailings as cement additive at $0 \%, 5 \%$ and $10 \%$ addition level by mass. Similarly, $361 \mathrm{~g}$ of cement containing copper tailings as an additive at of $0 \%, 5 \%$ and $10 \%$ by mass, $39 \mathrm{~g}$ of gypsum, $1100 \mathrm{~g}$ standard sand and $194 \mathrm{~mL}$ water were used for the preparation of potential sulfate expansion test mortar mixtures. At a constant $\mathrm{w} / \mathrm{b}$ ratio of 0.57 , concrete mixtures incorporating copper tailings at $0 \%, 5 \%$ and $10 \%$ addition levels were also prepared. These mixtures were identified as C0 for control, C5 and C10 for mixtures containing copper tailings. On completion of casting operations, specimens were kept in the curing room for 24 hours before they were then de-molded and left in the room at a temperature of $23.0 \pm 2.0^{\circ} \mathrm{C}$ and humidity of $85 \pm 5 \%$ until the time of testing. The mixture proportions are summarized in Table 2.

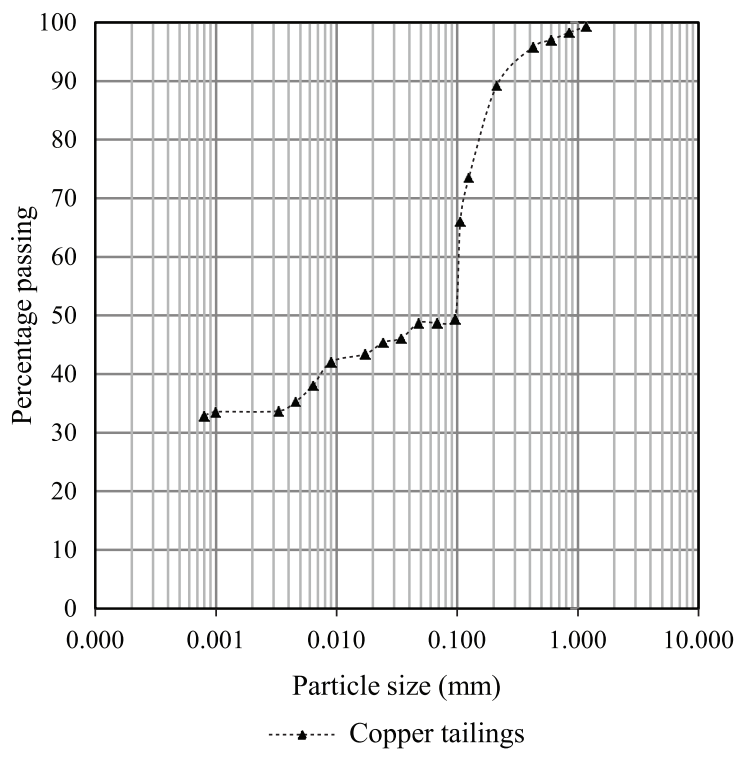

Figure 1. Particle size distribution.

Table 1. Chemical and physical properties of cement (CEM III A $32.5 \mathrm{~N}$ ) and copper tailings.

\begin{tabular}{ccc}
\hline Component & CEM III A & $\begin{array}{c}\text { Copper } \\
\text { tailing }\end{array}$ \\
\hline Chemical composition $(\%)$ & 29.15 & 11.20 \\
$\mathrm{SiO}_{2}$ & 7.34 & - \\
$\mathrm{Al}_{2} \mathrm{O}_{3}$ & 2.42 & 85.30 \\
$\mathrm{Fe}_{2} \mathrm{O}_{3}$ & 50.04 & - \\
$\mathrm{CaO}$ & 3.99 & - \\
$\mathrm{MgO}$ & 1.97 & - \\
$\mathrm{SO}_{3}$ & 0.01 & - \\
$\mathrm{Cl}$ & 1.65 & - \\
Loss on ignition & 0.27 & - \\
Insoluble residue & & \\
Heavy metal content $(\mathrm{mg} / \mathrm{kg})$ & - & 2284 \\
$\mathrm{Cu}$ & - & 402 \\
$\mathrm{Zn}$ & - & 60 \\
$\mathrm{~Pb}$ & - & 12 \\
$\mathrm{Cr}$ & - & 0.86 \\
$\mathrm{Cd}$ & & \\
Bhysical properties & 2.96 & 4.29 \\
Specific gravity & 3440 & 537 \\
Absorption $(\%)$ & - & 13.82 \\
\hline
\end{tabular}


Table 2. Mixture proportions.

\begin{tabular}{cccccccc}
\hline W/B & Mixture & Tailings & \multicolumn{3}{c}{ Quantities (kg) } \\
\hline ratio & name & (\% by mass) & Water & Cement & Tailings & Fine & Coarse \\
\hline \multirow{2}{*}{0.57} & C0 & 0 & 225 & 395 & 0 & 810 & 950 \\
& C5 & 5 & 225 & 395 & 20 & 810 & 950 \\
& C10 & 10 & 225 & 395 & 40 & 810 & 950 \\
\hline
\end{tabular}

\subsection{Autoclave expansion}

The impact of copper tailings on $\mathrm{CaO}$, or $\mathrm{MgO}$, or both, induced delayed expansion of pastes was investigated in accordance with the ASTM C $151^{18}$ specification. For each mixture, a paste of normal consistency was mixed, and two $25 \mathrm{~mm} \times 25 \mathrm{~mm} \times 285 \mathrm{~mm}$ prisms were prepared by compacting the paste inside molds in two layers. After curing and de-molding, sample dimensions before test were determined with a length comparator. Samples were then placed in autoclave equipment, and temperature was adjusted until a steam pressure of $2.0 \mathrm{MPa}$ was attained within 45 minutes of start of test. This pressure was kept constant for 3 hours, before the heat supply was turned off. Thereafter, samples were removed and allowed to cool for 30 minutes in water before final lengths were measured. The changes in length of test samples were calculated by subtracting the length comparator measurements before and after autoclaving, which were then presented as a percentage of the effective gage length to the nearest $0.01 \%$.

\subsection{Percentage mass of absorbed water and volume of permeable voids}

After 90 days of curing, four $100 \mathrm{~mm} \times 52 \mathrm{~mm}$ cylindrical specimens were cut from the middle of four $100 \mathrm{~mm}$ diameter $\times 200 \mathrm{~mm}$ long cylinders, and used for the ASTM C $642^{19}$ test for the determination of percentage absorbed water and volume of permeable voids in concretes. These cracks and fissures free samples were oven dried to constant mass for 48 hours at $110^{\circ} \mathrm{C}$ before being immersed in water at $21^{\circ} \mathrm{C}$ for 48 hours. Samples were surface-dried with a towel before their saturated mass were determined. Thereafter, samples were boiled inside water for 5 hours and allowed to cool for 14 hours before their apparent mass in water were determined. The percentage absorption and volumes of voids were calculated using these oven dry mass, immersed apparent mass, immersed and boiled saturated mass values.

\subsection{Mechanical strength of concrete}

The compressive and splitting tensile strengths of all the concrete mixtures were determined at the same test ages using the BS EN 12390: Part 3: $2009^{20}$ and ASTM C $293^{21}$ guidelines. For each mixture, nine $150 \mathrm{~mm}$ cubes were used for the compressive strength tests at 7 days, 28 days and 90 days. Similarly, six $100 \mathrm{~mm} \times 100 \mathrm{~mm} \times 500 \mathrm{~mm}$ prisms were also used for flexural strength tests at 28 days and 90 days. For the compressive strength test, samples were placed in a compression test machine and loaded at a constant rate of $0.7 \mathrm{MPa} / \mathrm{s}$ until failure occurred. Similarly, prisms for the flexural strength (center-point loading) tests were subjected to a constant loading rate of $3.0 \mathrm{MPa} / \mathrm{min}$ until failure occurred.

\subsection{Sulfate resistance}

The effect of partial substitution of cement with copper tailings on the potential sulfate expansion of mortar prisms was investigated according to ASTM C $452^{15}$ specifications. Mortars containing $7.0 \%$ by mass sulfur trioxide (SO3) were mixed, and two $25 \mathrm{~mm} \times 25 \mathrm{~mm} \times 285 \mathrm{~mm}$ prisms were prepared by compacting mortar inside molds in two layers. Molds containing these samples were left in the curing room for 24 hours. After de-molding, samples were placed in water at $23 \pm 2{ }^{\circ} \mathrm{C}$ for 30 minutes before initial lengths were determined using a length comparator. Thereafter, samples were placed on supports inside a pan and covered with about $15 \mathrm{~mm}$ of water until the $14^{\text {th }}$ day. Samples were wiped dry with a damp cloth before their final lengths were determined. The expansion of samples was calculated as the difference in length of samples at 24 hours and 14 days to the nearest $0.001 \%$ of the effective gage length.

\subsection{Acid resistance}

The resistance of concrete samples to acid attack was evaluated after 90 days of air curing. First, initial mass of four $50 \times 50 \times 50 \mathrm{~mm}$ specimens taken from each mixture were determined before placement in 5\% hydrochloric acid solutions for 28 days. The acid solution was renewed after 14 days, and at the $28^{\text {th }}$ day of immersion, specimens were oven-dried to constant mass. Thereafter, detachable particles were removed and final masses were determined. The percentage mass losses of specimens were used as an indicator of resistance to acid attack.

\subsection{Rapid chloride permeability test (RCPT)}

RCPT evaluates the total charge transmitted through concrete specimens during a 6 hours period. For each mixture, the test was performed using three $100 \mathrm{~mm} \times 52 \mathrm{~mm}$ cylindrical specimens cut from the middle of three $100 \mathrm{~mm}$ diameter $\times 200 \mathrm{~mm}$ long cylinders. The test was carried out according to the ASTM C $1202^{22}$ guidelines. First, samples were placed in a desiccator and vacuumed for 3 hours before they were covered with water and vacuumed for additional 1 hour. Thereafter, samples were left under water for 18 hours before being tested. Samples were placed in the center of two test cells; the cell filled with $3.0 \%$ sodium chloride $(\mathrm{NaCl})$ solution was connected to the negative terminal while the cell filled with $0.3 \mathrm{~N}$ sodium hydroxide $(\mathrm{NaOH})$ solution was connected to the positive terminal of the power supply. A potential difference of $60 \mathrm{~V}$ was maintained across the test set up for 6 hours, and the total charge passed, in coulombs was determined. 


\subsection{Chloride immersion test}

Actual penetration of chloride ions into concrete specimens was verified by immersing four $50 \times 50 \times 50 \mathrm{~mm}$ cubic specimens coated on all but one side in a $3 \% \mathrm{NaCl}$ solution for 28 days. Thereafter, the specimens were split and sprayed with a $0.1 \mathrm{~N}$ silver nitrate solution as suggested by Otsuki et al..$^{23}$ to determine the chloride penetration depths. These depths were identified as points within the samples where free chlorides above $0.15 \%$ by mass of cement reacted with $0.1 \mathrm{~N}$ silver nitrate $\left(\mathrm{AgNO}_{3}\right)$ solution to form a white precipitate of silver chloride $(\mathrm{AgCl})$. The absence or limited availability of free chloride was signified by brown coloration produced from the reaction of $\mathrm{AgNO}_{3}$ solution and hydroxides in the concrete samples.

\section{Results and Discussion}

\subsection{Autoclave expansion}

The results of the autoclave expansion tests are shown in Figure 2. The expansion values of the paste mixtures were $0.036 \%$ for $\mathrm{C} 0,0.023 \%$ for $\mathrm{C} 5$ and $0.031 \%$ for $\mathrm{C} 10$. These results are significantly low; and the best performances were obtained from the C5 mixtures, followed by the C10 samples. In a related study, Liu et al. ${ }^{24}$ equally observed increased resistance to autoclave expansion in fly ash and slag blended paste mixtures. The improved resistance of copper tailings blended pastes was attributed to the accelerated hydration reaction induced by autoclave curing, which produced enhanced strength and microstructure in copper tailings pastes.

\subsection{Percentage mass of absorbed water and volume of permeable voids}

Figure 3 shows the results of water absorption and volume of permeable voids properties of concretes at the age of 90 days. The percentage mass of absorbed water were $6.3 \%$ for $\mathrm{C} 0,6.8 \%$ for $\mathrm{C} 5$ and $7.5 \%$ for $\mathrm{C} 10$. These results suggest that compared to the control mixture, copper tailings blended concretes have higher permeable voids, hence the marginal increases in water absorption observed. The percentage volumes of permeable voids were $15.7 \%$ for $\mathrm{C} 0$, $16.4 \%$ for $\mathrm{C} 5$ and $18.1 \%$ for $\mathrm{C} 10$. Increased absorbed water

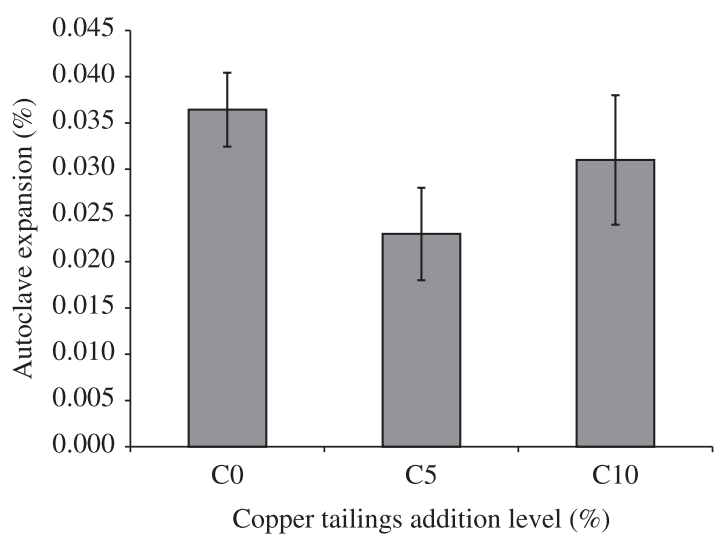

Figure 2. Autoclave expansion of pastes. and pore volumes were also observed by Hadj-sadok et al..$^{25}$, in mortars containing moderately reactive ground granulated blast furnace slag. The slightly increased percentage mass of absorbed water and total permeable voids of copper tailings blended concretes in this study was attributed to the porous and coarse particles of the tailings. Nevertheless, pore refinement and interconnectivity reduction by the fine particles of these tailings may ensure that the increased porosity of copper tailings blended mixtures does not impair durability properties.

\subsection{Mechanical strength of concrete}

Figure $4 \mathrm{a}$ shows the compressive strength results of concrete specimens. These results showed that at all test ages, C5 and C10 mixtures yielded higher compressive strengths compared to the control mixture. The observed percentage compressive strengths relative to the control at the $7^{\text {th }}$ day were $105.8 \%$ for $\mathrm{C} 5$ and $\mathrm{C} 10$, respectively. Similarly, the observed percentage compressive strengths relative to the control at the $28^{\text {th }}$ day were $107.1 \%$ for $\mathrm{C} 5$ and $104.1 \%$ for $\mathrm{C} 10$ while that of the $90^{\text {th }}$ day were also $112.3 \%$ for $\mathrm{C} 5$ and $109.2 \%$ for $\mathrm{C} 10$. The percentage relative increases in compressive strength of these mixtures between the $28^{\text {th }}$ and the $90^{\text {th }}$ day were $10.9 \%$ for $\mathrm{C} 0,16.2 \%$ for $\mathrm{C} 5$ and $16.3 \%$ for $\mathrm{C} 10$. Moura et al. ${ }^{26}$ observed similar trend in the compressive strength of concrete containing copper slag as an additive. It is suspected that slightly reduced w/b ratio, the filler effect of fine particles of the tailings and additional hydration products at later age contributed to the compressive strength enhancement witnessed in the blended mixtures. Similarly, Figure $4 \mathrm{~b}$ shows that at the $28^{\text {th }}$ day, the flexural strengths of the blended mixtures compared to the control samples were $122.7 \%$ for C5 and $127.3 \%$ for $\mathrm{C} 10$. At the $90^{\text {th }}$ day, these values improved to $125.0 \%$ for $\mathrm{C} 5$ and $128.3 \%$ for $\mathrm{C} 10$. The percentage relative increases in flexural strength of these mixtures between the $28^{\text {th }}$ and the $90^{\text {th }}$ day were $36.4 \%$ for $\mathrm{C} 0,38.9 \%$ for $\mathrm{C} 5$ and $37.5 \%$ for $\mathrm{C} 10$. In addition to these aforementioned

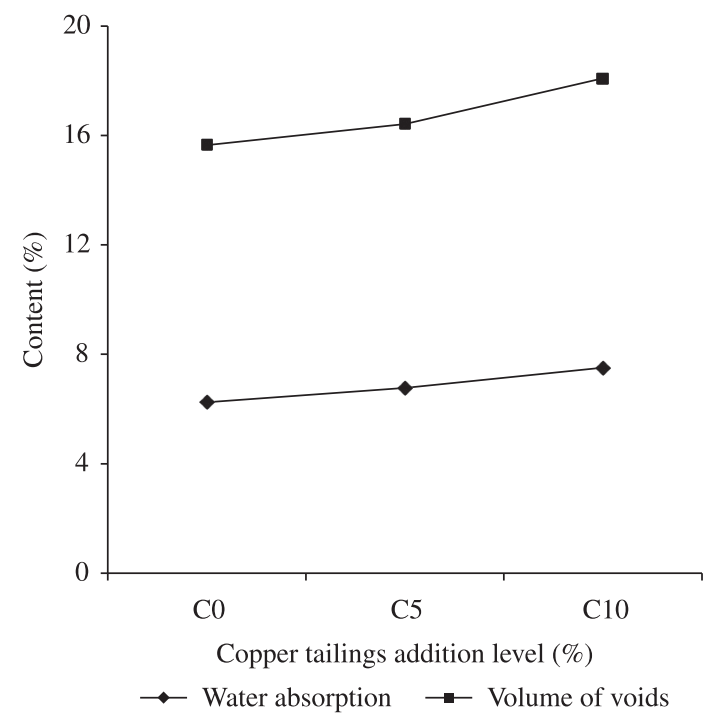

Figure 3. Water absorption and volume of permeable voids in concretes. 


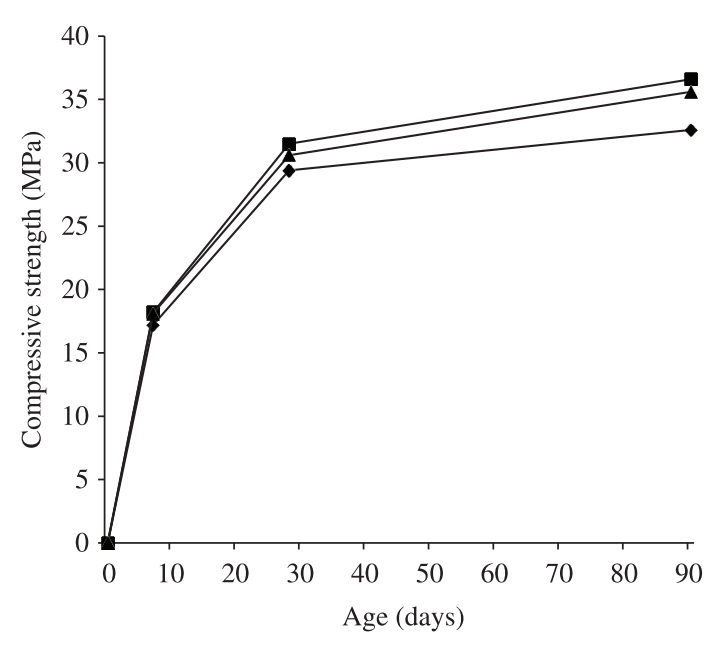

(a)

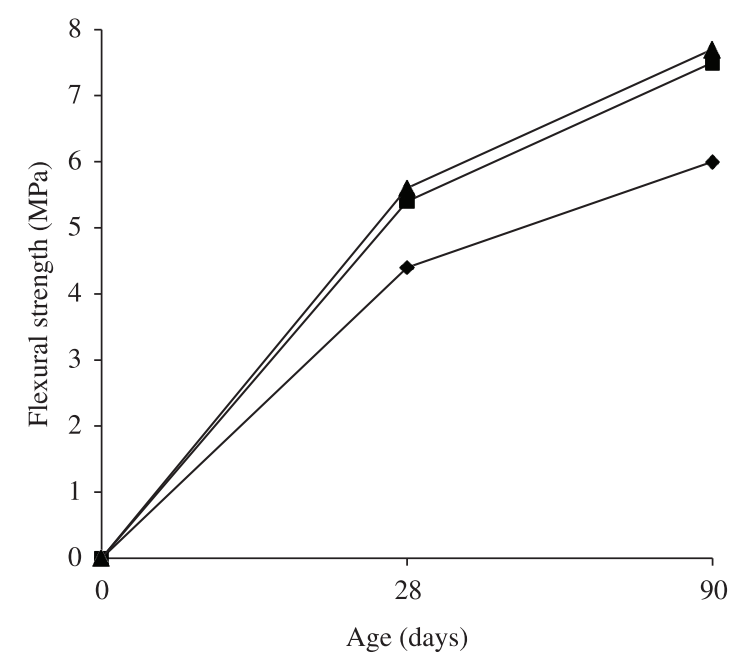

(b)

Figure 4. a) Relationship between compressive strength and copper tailings addition level; b) Relationship between flexural strength and copper tailings addition level.

compressive strength enhancement factors, the increased flexural strengths of these blended samples could be as a result of improved bonding between aggregates and pastes engendered by these copper tailings.

\subsection{Potential sulfate expansion}

The percentage change in length of mortar samples are shown in Figure 5. The values were $0.043 \%$ for C $0,0.046 \%$ for $\mathrm{C} 5$ and $0.050 \%$ for $\mathrm{C} 10$. The negligible expansion of the $\mathrm{C} 0$ samples which are comparable to the ASTM C $150^{27}$ limit of $0.04 \%$ for sulfate resisting cement was attributed to the low tricalcium aluminate $\left(\mathrm{C}_{3} \mathrm{~A}\right)$ content of the slag cement used. It was expected that similar or lower expansions compared to those of the control samples will be obtained in blended samples since their $\mathrm{C}_{3} \mathrm{~A}$ contents are same. However, slight increases in expansion values as tailings content of blended samples became higher were observed. This irregular occurrence is traceable to the increased sulfate permeation of these tailings blended samples which intensified the formation of gypsum and expansive ettringite in samples. Furthermore, the reduced rate of early strength gain caused by the delayed hydration of cement induced by heavy metals present in copper tailings may have also contributed to the increased expansion. Lee et al. ${ }^{28}$ investigated the sulfate resistance of mortars containing recycled fine aggregates as a partial replacement of natural fine aggregate and they suggested that the high water absorption characteristics of these aggregates contributed immensely to the increased expansion observed in specimens. Poor sulfate resistance compared to those of Type I/V control concretes after 48 months exposure to sulfate environment, was observed by Hossain ${ }^{29}$ in concretes containing porous volcanic scoria. Similarly, Najimi et al. ${ }^{13}$ observed improved sulfate resistance in concretes containing copper slag, and they attributed the performance to the reduced permeability of these concretes. Therefore, the increased expansion of the $\mathrm{C} 5$ and $\mathrm{C} 10$ samples is attributed to their higher water permeation compared to the control.

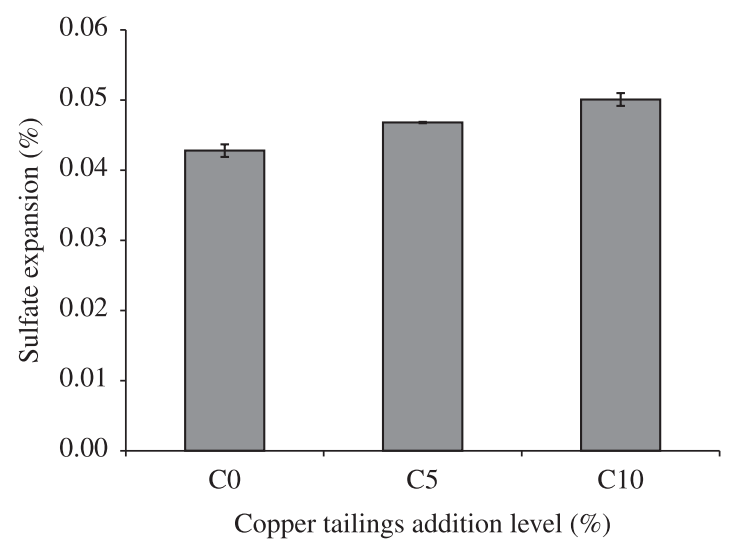

Figure 5. Potential sulfate expansion of mortars.

\subsection{Acid resistance}

Figure 6 highlights the mass loss of concrete samples after exposure to aqueous $5 \% \mathrm{HCl}$ solution for 28 days. The percentage losses in mass were $5.7 \%$ for $\mathrm{C} 0,3.1 \%$ for $\mathrm{C} 5$ and $2.6 \%$ for $\mathrm{C} 10$. Compared to the copper tailings blended samples, the $\mathrm{C} 0$ samples contained higher quantities of $\mathrm{Ca}(\mathrm{OH})_{2}$. Thus, the highest loss of mass recorded in the $\mathrm{C} 0$ samples was probably as a result of the dissolution and leaching away of $\mathrm{Ca}(\mathrm{OH})$, present on sample surfaces by the aqueous $\mathrm{HCl}$ acid solution. This heightened surface decomposition predisposed the interior of $\mathrm{C} 0$ specimens to increased acid attack and deterioration. Conversely, the lower percentage mass loss in samples containing copper tailings was attributed to secondary hydration reaction induced by copper tailings, which reduced the $\mathrm{Ca}(\mathrm{OH})_{2}$ available for acid attack in samples. Moreover, denser microstructure and greater bonding of particles in samples induced by the coarse and porous tailings may have also contributed to the enhanced resistance against acid attack. Chindaprasirt et al. ${ }^{30}$ observed enhanced acid resistance as the fineness of fly ash in blended mortar samples decreased. 


\subsection{Rapid chloride permeability test}

Figure 7 shows the total charge transmitted through concrete specimens after the RCPT test. Air curing method used in this study may have contributed to the high charge recorded. It was observed that the total charge transmitted through the copper tailings blended mixtures were higher than that of the control mixture. This occurrence was because of the presence of copper in the tailings, which led to the increased conductivity of C5 and $\mathrm{C} 10$ specimens during the tests. However, the lower charge of $\mathrm{C} 10$ samples compared to that of the $\mathrm{C} 5$ samples was attributed to restrained transmissibility caused by enhanced pore refinement at higher tailings content. Based on RCPT results, several studies have shown that as the supplementary cementitious material content of concrete increases, chloride permeability of concrete specimens decrease accordingly. Nonetheless, Shi et al. ${ }^{31}$ averred that total transmitted charge should not be used as a determinant of the chloride penetration resistance of concretes containing supplementary cementing materials. Wee et al. ${ }^{32}$ were also of the opinion that the charge transmitted through concrete containing supplementary cementitious materials indicate its overall electrical conductivity rather than its resistance to chloride penetration. Further studies by $\mathrm{Shi}^{33}$ showed that supplementary cementing materials can significantly influence the chemistry or electrical conductivity of pore

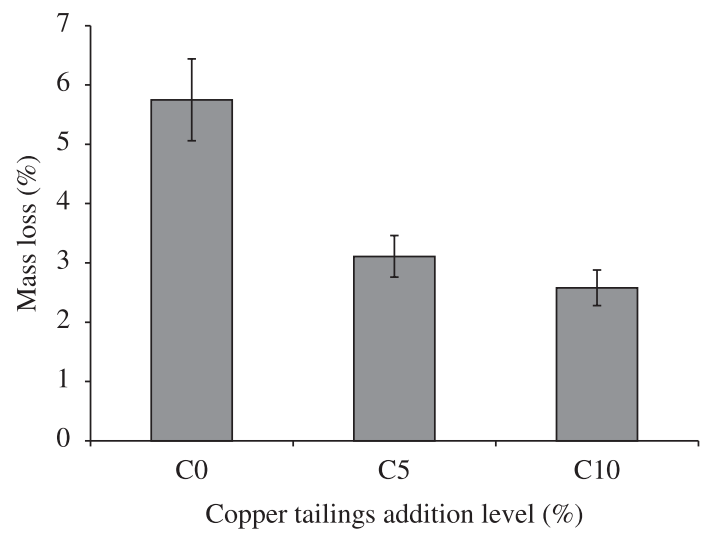

Figure 6. Acid resistance of concretes.

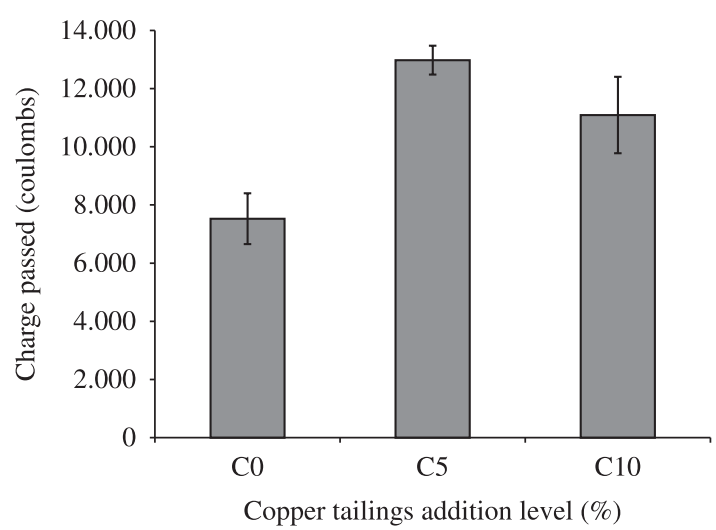

Figure 7. Rapid chloride permeability test of concrete. solution. Hence, the use of RCPT as a means of determining chloride permeability of blended concretes is invalid. Therefore, the result obtained from copper tailings blended concretes were probably a measure of sample conductivity rather than chloride permeability. In a related submission, Naik et al..$^{34}$ suggested that increased water content of samples and concentration of ions in pore solution decreases the resistivity of cement pastes. The high conductivity of concretes containing copper tailings could be utilized in the deicing of roadways and electromagnetic shielding of electrical and electronic devices.

\subsection{Chloride immersion test}

Figure 8 shows the chloride penetration depths in samples. The depths of penetration were $19.9 \mathrm{~mm}$ for $\mathrm{C} 0,7.6 \mathrm{~mm}$ for $\mathrm{C} 5$ and $3.4 \mathrm{~mm}$ for C10 samples. These results showed that concrete mixtures containing copper tailings had enhanced chloride penetration resistance compared to the control samples. The reduced depths of chloride penetration witnessed in these blended samples were attributed to reduced $w / b$ ratio due to the absorption of mix water and refinement of voids which led to a discontinuous pore structure in the concretes. Furthermore, chemical reaction between copper tailings and chlorides may have caused a decrease in the soluble chloride content and migration in samples. Figure 9 shows the correlation between the total charge passed and chloride penetration depths for these concretes. The graph highlights an inverse relationship whereby chloride penetration depths decreased as charge passed increased. However, the determined $\mathrm{R}^{2}$ value of 0.69 suggests a weak linear correlation between the two variables. Lack of correlation between chloride penetrations and RCPT values obtained from concrete samples containing GGBFS and SF was also reported by Wee et al. ${ }^{32}$ In a related investigation of concretes made with different types of binders, Meck and Sirivivatnanon ${ }^{35}$ equally observed poor correlation between RCPT test results and chloride penetration depths obtained from immersion tests.

Hence, in this study, these two tests are independent of each other, and are affected by different factors. While RCPT results were influenced by the increased conductivity of samples induced by copper contained in the tailings, chloride penetration depth values were mainly dependent

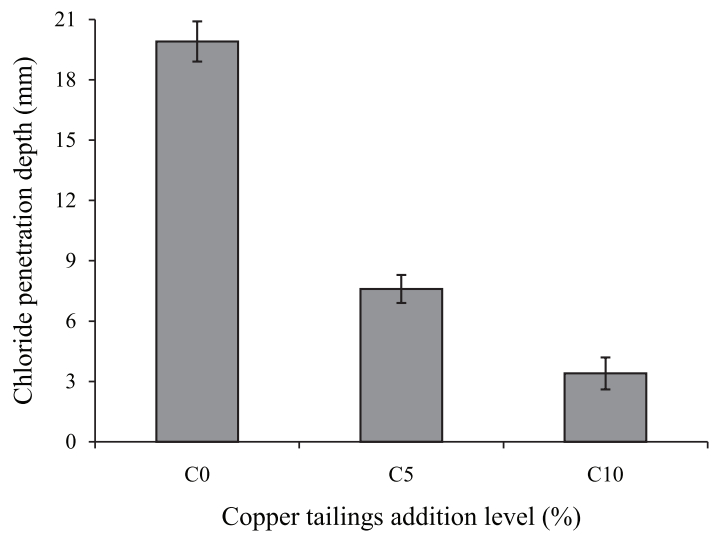

Figure 8. Depth of chloride penetration of concrete. 


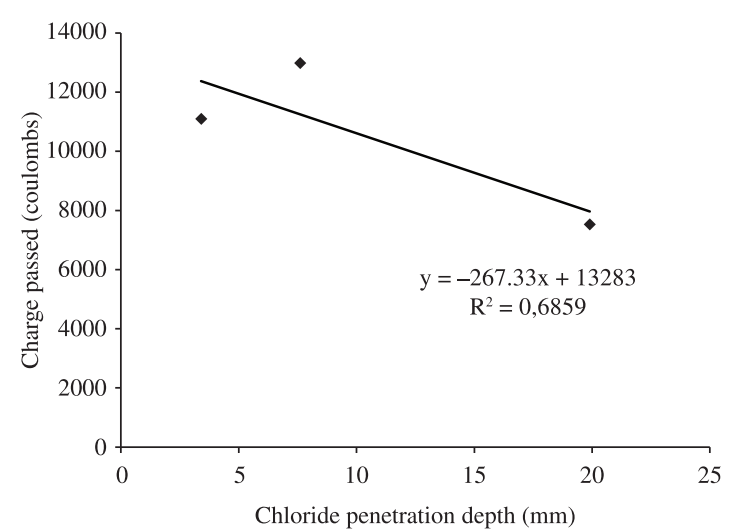

Figure 9. Correlation between the chloride penetration depth and RCPT test results.

on sample microstructure, pore interconnectivity and the chemical reaction between metals in the tailings and the chlorides. Moreover, the anomalous behavior observed by comparing data in Figure 3 and Figure 8, whereby depth of chloride penetration decreased as the water absorption of samples increased signifies that percentage water absorption is not a good indicator of the chloride resistance property of these concretes. Similar observations about the unreliability of water absorption as an indicator of chloride migration in concrete, was made by De Schutter and Audenaert ${ }^{36}$.

\section{Conclusion}

The use of copper tailings as an additive caused a reduction in autoclave expansion of pastes. However, the percentage mass of absorbed water and volume of permeable voids increased slightly as the copper tailings addition level in concrete became higher;

\section{References}

1. Langely WS, Carette VM and Malholtra VM. High fly ash structural concrete. ACI Materials Journal. 1989; 86(5):507-513.

2. Polder RB and Peelen WHA. Characterisation of chloride transport and reinforcement corrosion in concrete under cyclic wetting and drying by electrical resistivity. Cement and Concrete Composite. 2002; 24(5):427-435. http://dx.doi. org/10.1016/S0958-9465(01)00074-9

3. Hou $\mathbf{J}$ and Chung DDL. Effect of admixtures in concrete on the corrosion resistance of steel reinforced concrete. Corrosion Science, 2000; 42:1489-1507. http://dx.doi.org/10.1016/ S0010-938X(99)00134-1

4. Ganesan K, Rajagopal K and Thangavel K. Evaluation of bagasse ash as supplementary cementitious material. Cement and Concrete Composite 2007; 29(6):515-524. http://dx.doi. org/10.1016/j.cemconcomp.2007.03.001

5. Cordeiro GC, Toledo Filho RD, Tavares LM and Fairbairn ER. Ultrafine grinding of sugar cane bagasse ash for application as pozzolanic admixture in concrete. Cement and Concrete Research. 2009; 39(2):110-115. http://dx.doi.org/10.1016/j. cemconres.2008.11.005
The compressive strength results showed that the addition of copper tailings to concrete led to higher strengths compared to the control concrete at the $7^{\text {th }}, 28^{\text {th }}$ and $90^{\text {th }}$ days. Maximum compressive strength was obtained from the C5 samples. Similarly, all the concrete mixtures incorporating copper tailings recorded higher flexural strengths compared to the control at all test ages.

The increased water permeability of mortar specimens containing copper tailings slightly impaired resistance to sulfate expansion. The reduction in resistance became more apparent as the copper tailings content in samples increased;

Conversely, the addition of copper tailings to concrete increased its resistance to acid attack. And this became more significant as tailings content in samples increased;

Copper tailings increased the conductivity of concretes. Hence, the RCPT values obtained may not be a valid indicator of chloride ion migration in samples;

Actual chloride penetration obtained from the immersion test, showed that copper tailings blended concretes recorded significantly lower chloride penetration depths compared to those of the control samples. Furthermore, regression analysis highlighted the poor correlation between RCPT test and the immersion test;

Finally, findings from this paper suggest that that copper tailings can potentially enhance the durability properties of cement based materials. The increased conductivity of copper tailings blended concretes could also be applied in deicing of roadways, runways and bridges in very cold weather countries.

\section{Acknowledgements}

We would like to express thanks to Mr. Ogün Kilıç of the Materials of Construction Laboratory, Department of Civil Engineering, EMU, for his support during the experimental testing program.
6. Chusilp N, Jaturapitakkul C and Kiattikomol K. Utilization of bagasse ash as a pozzolanic material in concrete. Construction and Building Materials. 2009; 23(11):3352-3358. http://dx.doi. org/10.1016/j.conbuildmat.2009.06.030

7. International Copper Study Group - ICSG. The World Copper Fact Book. Lisbon: ICSG; 2009. p. 28-30.

8. Boger DV. Rheology and the resource industries. Chemical Engineering Science. 2009; 64:4525-4536. http://dx.doi. org/10.1016/j.ces.2009.03.007

9. Huang X, Ni W, Cui W, Wang Z and Zhu L. Preparation of autoclaved aerated concrete using copper tailings and blast furnace slag. Construction and Building Materials. 2012; 27:1-5. http://dx.doi.org/10.1016/j.conbuildmat.2011.08.034

10. Ayano T and Sakata K. Durability of concrete with copper slag fine aggregate. In: Proceedings of the 5th CANMET/ACI International Conference on Durability of Concrete; 2000; Barcelona, Spain. Barcelona; 2000. SP-192, p.141-158.

11. Moura WA, Gonçalves JP and Lima MB. Copper slag waste as a supplementary cementing material to concrete. Journal of Material Science. 2007; 42(7):2226-2230. http://dx.doi. org/10.1007/s10853-006-0997-4 
12. Al-Jabri KS, Hisada M, Abdullah H, Al-Saidy AH and Al-Oraimi SK. Performance of high strength concrete made with copper slag as a fine aggregate. Construction and Building Materials. 2009; 23:2132-2140. http://dx.doi.org/10.1016/j. conbuildmat.2008.12.013

13. Najimi M, Sobhani J and Pourkhorshidi AR. Durability of copper slag contained concrete exposed to sulfate attack. Construction and Building Materials. 2011; 25(4):1895-1905. http://dx.doi.org/10.1016/j.conbuildmat.2010.11.067

14. American Society for Testing and Materials - ASTM. ASTM C778: Standard Specification for Standard Sand. Philadelphia: ASTM; 2006.

15. American Society for Testing and Materials - ASTM. ASTM C452 / C452M: Standard Test Method for Potential Expansion of Portland-Cement Mortars Exposed to Sulfate. Philadelphia: ASTM; 2010.

16. American Society for Testing and Materials - ASTM. ASTM $C$ 188: Standard Test Method for Density of Hydraulic Cement. Philadelphia: ASTM; 2009.

17. American Society for Testing and Materials - ASTM. ASTM C 204: Standard Test Methods for Fineness of Hydraulic Cement by Air-Permeability Apparatus. Philadelphia: ASTM; 2007.

18. American Society for Testing and Materials - ASTM. ASTM C 151: Standard Test Method for Autoclave Expansion of Hydraulic Cement. Philadelphia: ASTM; 2009.

19. American Society for Testing and Materials - ASTM. ASTM C 642: Standard Test Method for Density, Absorption, and Voids in Hardened Concrete. Philadelphia: ASTM; 2006.

20. British Standard Institution - BSI. BS EN 12390-3: Testing hardened concrete - Part 3: Compressive strength of test specimens. London: BSI; 2009.

21. American Society for Testing and Materials - ASTM. ASTM C 293: Standard Test Method for Flexural Strength of Concrete (Using Simple Beam with Center-Point Loading). Philadelphia: ASTM; 2008.

22. American Society for Testing and Materials - ASTM. ASTM C 1202: Standard Test Method for Electrical Indication of Concrete's Ability to Resist Chloride Ion Penetration. Philadelphia: ASTM; 2010.

23. Otsuki N, Nagataki S and Nakashita K. Evaluation of $\mathrm{AgNO}_{3}$ solution spray method for measurement of chloride penetration into hardened cementitious matrix materials. ACI Material Journal. 1989; 89(6):587-592.

24. Liu Z, Tang M and Cui X. Expansion of Cement Containing Crystalline Magnesia With and Without Fly Ash and Slag. Cement, Concrete and Aggregates. 1998; 20(1):180-185. http:// dx.doi.org/10.1520/CCA10452J

25. Hadj-sadok A, Kenai S, Courard L and Darimont A. Microstructure and durability of mortars modified with medium active blast furnace slag. Construction and Building
Materials. 2011; 25(2):1018-1025. http://dx.doi.org/10.1016/j. conbuildmat.2010.06.077

26. Moura W, Masuero A, Molin D and Dal Vilela A. Concrete performance with admixtures of electrical steel slag and copper slag concerning mechanical properties. In: Proceedings of the 2nd CANMET/ACI International Conference on High Performance Concrete; 1999; Gramado, Brazil. Gramado; 1999. SP-186, p. 81-100.

27. American Society for Testing and Materials - ASTM. ASTM C 150: Standard Specification for Portland Cement. Philadelphia: ASTM; 2009.

28. Lee ST, Moon HY, Swamy RN, Kim SS and Kim JP. Sulfate Attack of Mortars Containing Recycled Fine Aggregates. ACI Material Journal. 2005; 102(4):224-230.

29. Hossain KMA. Resistance of Scoria-Based Blended Cement Concrete against Deterioration and Corrosion in Mixed Sulfate Environment. Journal of Materials in Civil Engineering. 2009; 21(7):299-308. http://dx.doi.org/10.1061/ (ASCE)0899-1561(2009)21:7(299)

30. Chindaprasirt $P$, Homwuttiwong $S$ and Sirivivatnan V. Influence of fly ash fineness on strength, drying shrinkage and sulfate resistance of blended cement mortar. Cement and Concrete Research. 2004; 34(7):1087-1092. http://dx.doi.org/10.1016/j. cemconres.2003.11.021

31. Shi C, Stagemann JA and Caldwell RJ. Effect of Supplementary Cementing Materials on the Specific Conductivity of Pore Solution and its Implications on the Rapid Chloride Permeability Test (AASHTO T277 and ASTM C1202) Results. ACI Materials Journal. 1998; 95(4):389-393.

32. Wee TH, Suryavanshi AK and Tin SS. Evaluation of Rapid Chloride Permeability Test (RCPT) Results for Concrete Containing Mineral Admixtures. ACI Materials Journal. 2000; 97(2):221-232.

33. Shi C. Effect of mixing proportions of concrete on its electrical conductivity and the rapid chloride permeability test (ASTM C1202 or ASSHTO T277) results. Cement and Concrete Research. 2004; 34(3):537-545. http://dx.doi.org/10.1016/j. cemconres.2003.09.007

34. Naik TR, Kraus, RN, Ramme BW, Chun YM and Kumar R. High-Carbon Fly Ash in Manufacturing Conductive CLSM and Concrete. Journal of Materials in Civil Engineering. 2006; 18(6):743-746. http://dx.doi.org/10.1061/ (ASCE)0899-1561(2006)18:6(743)

35. Meck E and Sirivivatnanon V. Field indicator of chloride penetration depth. Cement and Concrete Research, 2003; 33(8):1113-1117. http://dx.doi.org/10.1016/ S0008-8846(03)00012-7

36. De Schutter G and Audenaert K. Evaluation of water absorption of concrete as a measure for resistance against carbonation and chloride migration. Materials and Structures. 2004; 37(9):591-596. http://dx.doi.org/10.1007/ BF02483288 